\title{
Asthma treatment with its relation to changes in seasonal metabolism
}

\author{
Tarun Saxena ${ }^{1}$, Azeema Ozefa Ali $^{2}$ and Manjari Saxena ${ }^{3}$ \\ ${ }^{1}$ Department of Internal Medicine, Mittal Hospital and Research Centre, India \\ ${ }^{2}$ B.H.M.S Resident, Mittal Hospital and Research Centre, India \\ ${ }^{3}$ Department Yoga and Physical Education, Mittal Hospital and Research Centre, India
}

\begin{abstract}
Seasonal asthma/ post viral asthma produces epidemic like condition in developed and developing countries which causes a huge burden to the society socially as well as economically with an increase in morbidity and mortality. This review highlights the preventive steps in controlling seasonal asthma symptoms.
\end{abstract}

\section{Introduction}

The worldwide incidences of bronchial asthma are increasing. The correlation between metabolism (basal metabolic rate/BMR) and asthma treatment is less clear in the literature due to the presence of multiple risk factors in the causation of asthma. Seasonal variations are also reported in both BMR and asthma [1-7].

\section{Methods}

Various studies have been used to review the process [1-16].

Results: Studies describe that metabolism changes with environmental temperature and season. It is also found that the asthma epidemic occurs during the change of season i.e. winter to summer, maximum attack rate during spring; and summer to winter, maximum attack rate during autumn/pre-winter. A clear association of asthma exacerbation and exposure to environmental air temperature is found. If environmental temperature opposes existing metabolism e.g. rise in temperature during spring tries to reduce BMR opposite to high BMR of winters and conversely in autumn low BMR of summer is opposed by mild cool air in pre winter. This alteration exacerbates asthma symptoms. In winter and spring, the metabolism remains high and asthma symptoms respond well to substances which increase the metabolic rate, such as clove. In summer and autumn, the metabolism remains low and asthma symptoms respond well to substances which reduce the metabolic rate, like rose petal jam $[1,2,3,7]$.

\section{Conclusion}

The possible mechanism by which change in metabolism affects inflammation in the tracheobronchial tree seems to involve the respiratory tract, as one of the sites of heat and water release and thermoregulation in the body.

During Winter/spring there is a high metabolic state which causes heat preservation in the body along with the respiratory tract. When there is an increase in temperature or any viral exposure then it opposes the existing metabolism of the body which leads to heat or water release in the body as well as in the respiratory tract in the form of inflammation in the respiratory tract with exacerbation of asthmatic symptoms. When such patients are administered hot substances like clove which has properties to increase the body metabolism will revert to its previous metabolism. Thus there will be heat preservation in the body and respiratory tract and decrease in inflammation in the respiratory tract and this, in turn, will help to reduce the symptoms of asthma.

During Summer/Autumn there is a low metabolic state which causes heat and water release in the body and respiratory tract. When there is a decrease in environmental temperature or any viral exposure then it opposes the existing metabolism of the body which leads to heat or water in the preservation in the body as well as in the respiratory tract in the form of inflammation in the respiratory tract with exacerbation of asthmatic symptoms. When such patients are administered cooling substances like rose petal jam which has properties to decrease the body metabolism will revert to its previous metabolism. Thus there will be heat or water release in the body and respiratory tract and decrease in inflammation in the respiratory tract and this, in turn, will help to reduce the symptoms of asthma.

Respiratory viruses enter into the body through the respiratory tract but enter into the bloodstream produce fever and affect thermoregulatory mechanism at the central level (hypothalamus).

\section{Preventive steps/Clinical implications}

Do's and Don'ts for the prevention of asthmatic attacks during Summer/Autumn

Do's:

1. Add various cooling substances like seasonal fruits, seasonal vegetables, amla (phyllanthus embilica/Indian gooseberry), buttermilk, rose petal jam, cardamom in your daily diet.

${ }^{*}$ Correspondence to: Tarun Saxena, Department of Internal Medicine, Mittal Hospital and Research Centre, Ajmer, Rajasthan, India, Tel: +91-9829089284, E-mail: yogdiab@gmail.com/info@mittalhospital.com

Received: June 07, 2019; Accepted: June 21, 2019; Published: June 24, 2019 
2. Asthmatic patients should go for an early morning walk from April to October regularly, this helps in body adaptation to cool air is useful to prevent an asthmatic attack during winters.

3. Asthmatic patients should do Yoga/exercises in the morning hours in the open air, rooftop, and garden to develop adaption to the environment and increase lung capacity.

4. In the post-viral asthma symptoms in summer season centrally acting substances which have a cool effect on the body/reduce BMR like Shankhpuspi (Convolvulus pluricaulis) or Bhrami (Bacopa monneri) are useful.

\section{Don'ts}

1. Asthmatic patients should avoid spicy food, fast food which is hot in nature like pizza i.e. increases metabolism produces more burden to the heat releasing mechanism of the body.

2. Chilled drinks, icy cold water or cold drinks immediately after exposing yourself to intense heat (tries to give opposite signals to existing metabolism) and suddenly tries to change the BMR.

\section{Do's and Don'ts for the prevention of asthmatic attacks} during Winter/spring

\section{Do's}

1. Add spices that increase the BMR in your daily diet like cloves, bay leaves, black pepper.

2. Add intake of hot drinks like tea, coffee and soups regularly.

3. Take a generous amount of seasonal fruits and vegetables in your daily diet.

4. Asthmatics should keep windows closed to avoid the exposure to cool air.

5. Keep warm, wear a scarf around the mouth and nose while moving outdoor to avoid the cool air.

6. Control germs by washing one's hand regularly.

7. In post viral asthma symptoms in winter season centrally acting substances which have a warm effect on body/increases, BMR like coffee/tea/papaver somniferum are useful.

8. Children above 7-8 years should be exposed gradually to the temperature throughout the year which will provide natural adaptation to all the seasonal changes and thus help in the reduction of asthmatic in the future.

\section{Don'ts}

1. Avoid Yoga/exercises in morning hours in the open air, rooftop, garden, etc. to avoid exposure to cool air.
2. Avoid exposure to wood fire if you are sensitive to smoke.

Thus making a little change in diet and habits suitable to the existing seasonal metabolism can do wonders in controlling the symptoms of asthma. Hence, the kitchen spices affecting the body metabolism if used wisely can throw light to the untrodden paths in the treatment and management of asthma at a low and effective cost.

\section{References}

1. Saxena T, Maheshwari S, Saxena M (2011) Mild cool air- A risk factor for asthma exacerbations: Results of a retrospective study. JAPI 59: 624-628. [Crossref]

2. Murray CS, Poletti G, Kebadze T, Morris J, Woodcock A, et al. (2006) Study of modifiable risk factors for asthma exacerbations: virus infection and allergen exposure increase the risk of asthma hospitalization in children. Thorax 61: 376-382. [Crossref]

3. Van Ooijen AM, van Marken Lichtenbelt WD, van Steenhoven AA, Westerterp KR (2004) Seasonal Changes in metabolic \& temperature responses in cold air in humans. Physiol Behav 82: 545-553. [Crossref]

4. Van Ooijen AMJ, Van Marken Lichtenbelt WD, Westerterp KR (2001) Individual differences in body temperature and the relation to energy expenditure: the influence of mild cold. $J$ Them Biol 26: 455-459.

5. van Marken Lichtenbelt WD1, Schrauwen P, van De Kerckhove S, WesterterpPlantenga MS (2002) Individual variation in body temperature and energy expenditure in response to mild cold. Am J Physiol Endocrinol Metab 282: E1077-1083. [Crossref]

6. O'Cain CF, Dowling NB, Slutsky AS, Hensley MJ, Strohi KP, et al. (1980) Airway effect of respiratory heat loss in normal subjects. J Appl Physiol Respir Environ Exerc Physiol 49: 875-880. [Crossref]

7. Saxena T, Patidar S, Saxena M, Bhabrawala A (2018) Asthma Treatment: Role of Metabolism from a Double-blind Randomized Control Trial. Exploratory Research and Hypothesis in Medicine 3: 6-13.

8. Bates GP, Miller VS (2008) Sweat rate and sodium loss during work in the heat. $J$ Occup Med Toxicol 3: 4. [Crossref]

9. Henry CJ, Emery B (1986) Effect of spiced food on metabolic rate. Hum Nutr Clin Nutr 40: 165-168. [Crossref]

10. Westerterp-Plantenga M, Diepvens K, Joosen AM, Bérubé-Parent S, Tremblay A (2006) Metabolic effect of spices, teas and caffeine. Physiol Behav 89: 85-91. [Crossref]

11. Rizvi MA, Ali SA (2016) Medicinal flowers of Pakistan. Int J Adv Res 4: 1313-1341.

12. Alagesaboopathi C (2012) Ethnobotanical studies on useful plants of Sirumalai Hills of Eastern Ghats Dindigul District of Tamilnadu, Southern India. Int J Biosci 2: 77-84.

13. WALKER JE, WELLS RE Jr, MERRILL EW (1961) Heat and water exchange in the respiratory tract. Am J Med 30: 259-267. [Crossref]

14. Robertshaw D (2006) Mechanisms for the control of respiratory evaporative heat loss in panting animals. J Appl Physiol (1985) 101: 664-668. [Crossref]

15. Farley RD, Albazzaz MK, Patel KR (1988) Role of cooling and drying in hyperventilation induced asthma. Thorax 43: 289-294. [Crossref]

16. Anderson SD, Schoeffel RE, Follet R, Perry CP, Daviskas E, et al. (1982) Sensitivity to heat and water loss at rest and during exercise in asthmatic patients. Eur J Respir Dis 63: 459-471. [Crossref]

Copyright: (C2019 Saxena T. This is an open-access article distributed under the terms of the Creative Commons Attribution License, which permits unrestricted use, distribution, and reproduction in any medium, provided the original author and source are credited. 